\title{
Türk dili ve edebiyatı öğretmenlerinin ölçme değerlendirme tutumlarını belirlemeye yönelik ölçek geliştirme çalışması: geçerlik ve güvenirlik
}

\section{Bahadır GÜCÜYETER²}

\section{Ahmet KARADOĞAN3}

\begin{abstract}
APA: Gücüyeter, B.; Karadoğan, A. (2019). Türk dili ve edebiyatı öğretmenlerinin ölçme değerlendirme tutumlarını belirlemeye yönelik ölçek geliștirme çalışması: geçerlik ve güvenirlik. RumeliDE Dil ve Edebiyat Araştırmaları Dergisi, (17), 47-6o. DOI: 10.2900o/rumelide.656614.
\end{abstract}

\section{$\ddot{\mathbf{O} z}$}

$\mathrm{Bu}$ çalışmanın amacı Türk dili ve edebiyatı öğretmenlerinin ölçme ve değerlendirmeye yönelik tutumlarını ölçmek amacıyla geçerli ve güvenilir bir tutum ölçeği geliştirmektir. Bu kapsamda ilgili alan yazın taraması yapılıp 84 maddeden oluşan madde havuzu oluşturulmuştur. Hazırlanan taslak ölçek, 4 ölçme değerlendirme uzmanı ve 2 dil uzmanının görüşlerine sunulmuş, gerekli düzeltmeler yapıldıktan sonra 48 maddelik taslak ölçek formu oluşturulmuştur. Taslak ölçek formu 2018- 2019 eğitim öğretim yılında Erzurum, Artvin, Ağrı, Bayburt, Bingöl, Kars, Elazı̆̆, Kütahya, Sivas, Trabzon, Samsun, Balıkesir, Van, Hatay, İstanbul, Afyon, Yalova, Kahramanmaraş, Gaziantep orta öğretim kurumlarında görev yapan 231 Türk dili ve edebiyatı öğretmenine uygulanmıştır. Ölçeğin faktör yapısını belirlemek amacıyla açımlayıcı ve doğrulayıcı faktör analizi yapılmıştır. Açımlayıcı faktör analizi sonuçlarına göre ölçek; 22 maddeden oluşan, \%62.09 toplam varyansa sahip ve 3 faktör altında toplanan bir yapı göstermiştir. Faktör yük değerlerinin ise .337 ile .945 arasında değiştiğ görülmüştür. Ölçeğin model uyumunun da iyi düzeyde olduğu sonucuna varılmıştır (X2/sd=2.1, RMSEA=.071, RMR= .034, $\mathrm{SRMR}=.054, \mathrm{NFI}=.96, \mathrm{NNFI}=.98, \mathrm{CFI}=.98, \mathrm{IFI}=.98, \mathrm{RFI}=.96$, GFI=.85). Araştırmadan elde edilen bulgular doğrultusunda, "Türk Dili ve Edebiyatı Öğretmenleri Ölçme Değerlendirme Tutum Ölçeği”nin Türk dili ve edebiyatı öğretmenlerinin ölçme değerlendirme tutumlarını ölçmede güvenirliği ve geçerliği olan bir ölçme aracı olduğu söylenebilir.

Anahtar kelimeler: Türk dili ve edebiyatı eğitimi, ölçme ve değerlendirme, tutum ölçeği.

\section{A scale development study to determine the assessment and evaluation attitudes of Turkish language and literature teachers: Validity and reliability}

\begin{abstract}
This study aims to develop a valid and reliable attitude scale to measure the attitudes of Turkish Language and Literature Teachers towards assessment and evaluation. In this context, the related literature was reviewed and an 84-item pool was created. The draft scale was reviewed by 4 assessment and evaluation experts and 2 language experts, and the 48-item draft scale form was created after the necessary corrections were made. The draft scale form was applied to 231 Turkish Language and Literature teachers working in secondary schools in Erzurum, Artvin, Ağrı, Bayburt,
\end{abstract}

Bu çalışma “Türk Dili ve Edebiyatı Öğretmenlerinin Ölçme Değerlendirme Tutum, Yeterlik ve Uygulamaları" adlı doktora tezinden üretilmiștir.

2 Prof. Dr., Atatürk Üniversitesi, Kâzım Karabekir Eğitim Fakültesi, Türkçe ve Sosyal Bilimler Eğitimi Bölümü, Türk Dili ve Edebiyatı ABD (Erzurum, Türkiye), bahadir@atauni.edu.tr, ORCID ID: oooo-0002-1041-9118 [Makale kaylt tarihi: 13.11.2019-kabul tarihi: 20.12.2019; DOI: 10.29000/rumelide.656614]

3 Arş. Gör., Atatürk Üniversitesi, Kâzım Karabekir Eğitim Fakültesi, Türkçe ve Sosyal Bilimler Eğitimi Bölümü, Türk Dili ve Edebiyatı Eğitimi ABD (Erzurum, Türkiye), karadoganahmet@hotmail.com, ORCID ID: oooo-ooo2-7183-3929 
A scale development study to determine the assessment and evaluation attitudes of Turkish language and literature teachers: Validity and reliability / B. Gücüyeter; A. Karadoğan (pp. 47-6o)

Bingöl, Kars, Elazığ, Kütahya, Sivas, Trabzon, Samsun, Balıkesir, Van, Hatay, İstanbul, Afyon, Yalova, Kahramanmaraş and Gaziantep during the 2018-2019 school year. Exploratory and confirmatory factor analyses were performed to determine the factor structure of the scale. According to the exploratory factor analysis results, the scale demonstrated a structure that consisted of 22 items, had a total variance of $62.09 \%$ and concentrated under three factors. It was observed that the factor loadings ranged between .337 and .945. It was also concluded that the model fit of the scale was at satisfactory levels $(\mathrm{X} 2 / \mathrm{sd}=2.1, \mathrm{RMSEA}=.071, \mathrm{RMR}=.034, \mathrm{SRMR}=.054, \mathrm{NFI}=.96, \mathrm{NNFI}=.98$, $\mathrm{CFI}=.98, \mathrm{IFI}=.98, \mathrm{RFI}=.96, \mathrm{GFI}=.85$ ). Based on the findings obtained in the study, it can be said that the "Assessment and Evaluation Attitude Scale for Turkish Language and Literature Teachers" is a valid and reliable tool to measure the assessment and evaluation attitudes of Turkish Language and Literature Teachers.

Keywords: Turkish language and literature education, assessment and evaluation, attitude scale.

\title{
Giriş
}

Eğitim bireylerin davranışlarında istenilen değişiklikler meydana gelmesini amaçlayan bir sistemdir (Turgut \& Baykul, 2015, s. 1). Bu sistemdeki istendik değişikliklerin eğitim öğretim yoluyla okullarda, dersler aracılığıyla bireylere kazandırıldığı düşünülürse bu sistem içerisinde tüm derslerin önemli olduğu yadsınamaz. Ancak Türk dili ve edebiyatı dersine ayrı bir yer vermek de gerekmektedir.

\begin{abstract}
"Kültürün taşıyıcısı olan dil hem en güzel şekliyle edebiyat eserlerinde yer aldığı, hem de hayatın ve hayata bakış tarzlarının neredeyse tamamı bu eserlere yansıtıldığı için bir milletin kültürü ile kültürlenerek eğitilmenin yolu da edebiyattan geçmektedir. Bu kültürlenme hem edebiyatımızın tarih içerisindeki macerasını öğrenme hem de edebiyat eserlerine yansıyan Türk kültürünün gelişim çizgisini izleme şeklinde ortaya çıkmaktadır” (Cemiloğlu, 2003, s. 45).
\end{abstract}

Edebiyat eserlerine yansıyan bu kültürel unsurların genç nesillere aktarılabileceği mekânların başında şüphesiz okullar gelmektedir. Bu kapsamda da Türk dili ve edebiyat öğretmenlerine büyük görev düşmektedir. Türk dili ve edebiyatı öğretmenlerine atfedilen bu görev dersler vasıtası ile verilebilecektir. $\mathrm{Bu}$ görevlerin ne kadarının başarıldığının belirlenmesinde ise ölçme değerlendirme etkin olarak kullanılacaktır.

Ölçme, sosyal araştırma içeriğinde geniş bir alanda önemli bir durumu teşkil etmektedir (DeVellis, 2014, s. 1). Bu önemli durum sosyal bilimlerde ölçme işleminin daha zor olmasından kaynaklanıyor denilebilir. Ölçme süreci ve hizmet ettiği daha geniş bilimsel sorular birbiriyle ilişkilidir; bunlar arasındaki sınırlar çoğunlukla fark edilmezler (DeVellis, 2014, s. 2). Ölçme en geniş anlamıyla, gözlem sonuçlarının sayılarla veya diğer nicel sembollerle gösterilmesi işlemidir (Turgut \& Baykul, 2015, s. 69), ilgilenilen niteliklerin (özelliklerin), amaca, araca ve olanaklara bağlı olarak nicelleştirilmesi (sayısallaştırılması) çabası, işlemi ve sürecidir (Erkuş, 2014, s. 7). Ölçme genel olarak doğrudan, dolaylı ve türetilmiş ölçme olarak üçe ayrılmaktadır.

Değerlendirme, gözlem sonuçlarının bir ölçüt veya ölçütlerle karşılaştııllarak bir karara varılması işidir (Turgut \& Baykul, 2015, s. 68). Girdilerden bir kısmı kontrol edilebilir, bir kısmı edilemez. Eğitim, kontrol edilemeyen girdileri yoğun olan sistemlerin başında gelir. Bu nedenle eğitim sisteminde değerlendirme, diğer sistemlere kıyasla hem daha önemli hem de zordur (Baykul, 2011, s. 1-2). Kizlik (2012) tarafından değerlendirme; İlerlemeyi izlemek ve gerektiğinde eğitim kararları almak için bilgi toplama süreci olarak tanımlanmıştır. Öğrencinin önceden belirlenmiş kriterleri karşılayıp karşılamadığını belirlemek için kullanılan prosedürlerdir. Bu, önceden belirlenmiş kriterlere uygun 
olarak bir yeterlilik belirlemesi yapmak için değerlendirme (bir değerlendirmenin bir test olabileceğini unutmayın) kullanılır (Kizlik, 2012).

Ölçme değerlendirme konularına programlarda geniş olarak yer verilip bu konuya vurgu yapılmakla birlikte Türk dili ve edebiyatı öğretmenlerinden istenen ölçme değerlendirme konularında öğretmenlerin tutumlarını belirlemek hem konunun eksiklerini gidermede hem de daha etkin ölçme ve değerlendirme yapma boyutunda önemli görülmektedir. Bu sebeple öncelikle Türk dili ve edebiyatı öğretmenlerinin ölçme değerlendirme tutumlarının ortaya konulması gerekmektedir denilebilir.

Türk dili ve edebiyatı derslerinin de kapsam ve içerik olarak birkaç kez değişen eğitim programlarında içerik ve ölçme değerlendirme kıstasları belirlenmiştir. 2018 programında ele alınan ölçme değerlendirme konusu ise bireysel farklara vurgu yaparak, "Hiçbir insan bir başkasının birebir aynısı değildir. Bu sebeple öğretim programlarının ve buna bağlı olarak ölçme ve değerlendirme sürecinin herkese uygun, herkes için geçerli ve standart olması insanın doğasına ters" (MEB, 2018) olarak belirlenmiştir. Bu sebeplere bağlı ölçme ve değerlendirme süreçlerinde ise azami derecede esneklik ve çeşitlilik anlayışına bağlı şekilde uygulanması şart koşulmuştur. Eğitim programının bu konudaki tüm ayrıntılara yer veremeyeceği belirtilerek "Eğitimde çeşitlilik; birey, eğitim düzeyi, ders içeriği, sosyal ortam, okul imkânları vb. iç ve dış dinamiklerden ciddi şekilde etkilendiği için, ölçme ve değerlendirme uygulamalarının etkililiğini sağlamada öncelik öğretim programlarından değil öğretmen ve eğitim uygulayıcılarından” (MEB, 2018) beklendiği ifade edilir. Bu esaslara göre yaratıcı ve özgün olmak öğretmenlerden istenen temel beklentidir.

Ayrıca 2018 öğretim programında liseyi bitiren bir öğrencinin, "ilkokulda ve ortaokulda kazandıkları yetkinlikleri geliştirmek suretiyle, millî ve manevi değerleri benimseyip hayat tarzına dönüştürmüş, üretken ve aktif vatandaşlar olarak yurdumuzun iktisadi, sosyal ve kültürel kalkınmasına katkıda bulunan, Türkiye Yeterlilikler Çerçevesi’nde ve ayrıca disiplinlere özgü alanlarda ifadesini bulan temel düzey beceri ve yetkinlikleri kazanmış, ilgi ve yetenekleri doğrultusunda bir mesleğe, yükseköğretime ve hayata hazır bireyler olmalarını sağlamak” (MEB, 2018) olarak belirtilmiştir.

Bunların dışında 2018 öğretim programında değerler de ele alınmış ve kök değerler belirlenmiştir. Bu öğretim programında değerler; "öğretim programlarının perspektifini oluşturan ilkeler toplamıdır. Kökleri geleneklerimiz ve dünümüz içinde, gövdesi ve dalları bu köklerden beslenerek bugünümüze ve yarınlarımıza uzanmaktadır. Temel insani özelliklerimizi oluşturan değerlerimiz, hayatımızın rutin akışında, karşılaştığımız sorunlarla başa çıkmada eyleme geçmemizi sağlayan kudretin ve gücün kaynağı (MEB; 2018)" olarak ifade edilmiştir.

2018 Türk Dili ve Edebiyatı Öğretim Programı’nda belirtilen "kök değerler” : “adalet, dostluk, dürüstlük, öz denetim, sabır, saygı, sevgi, sorumluluk, vatanseverlik, yardımseverlik (MEB, 2018)”. Bu değerlerin, "öğrenme öğretme sürecinde hem kendi başlarına, hem ilişkili olduğu alt değerlerle ve hem de öteki kök değerlerle birlikte ele alınarak hayat (MEB, 2018)” bulacağı belirtilmiştir.

Ayrıca 2017 ve 2018 programlarında güncel ölçme ve değerlendirme tekniklerinin kullanılması tavsiye edilmiştir. Öğrencilere kitap okutma konusu da ele alınmış ve dönemde bir kitap okutulması gerektiği belirtilmiştir. Bu kapsamda analiz, sentez ve değerlendirmeye öncelik verilerek sinavlarında buna göre hazırlanması gerektiği ifade edilmiştir. 
A scale development study to determine the assessment and evaluation attitudes of Turkish language and literature teachers: Validity and reliability / B. Gücüyeter; A. Karadoğan (pp. 47-6o)

Bütün bunlardan hareketle Türk dili ve edebiyatı öğretmenlerinin ölçme değerlendirme tutumlarının belirlenmesi oldukça önemli görülmüş ve bu çalışma planlanmıştır.

\section{Yöntem}

\section{Çalışma grubu}

Bir ölçek geliştirme çalışması olan bu araştırmanın çalışma grubunu 2018-2019 eğitim-öğretim yılı Erzurum, Artvin, Ağrı, Bayburt, Bingöl, Kars, Elazı̆̆, Kütahya, Sivas, Trabzon, Samsun, Balıkesir, Van, Hatay, İstanbul, Afyon, Yalova, Kahramanmaraş, Gaziantep illerinde görev yapan toplam 231 Türk dili ve edebiyatı öğretmeni oluşturmaktadır. Çalışmada kullanılan Uygun Örnekleme Yöntemi Büyüköztürk vd. (2013) tarafından araştırmacının ihtiyaç duyduğu büyüklükteki bir gruba ulaşana kadar en ulaşılabilir olan yanıtlayıcılardan başlayarak çalışma grubunu oluşturması ya da en ulaşılabilir ve maksimum tasarruf sağlayacak bir durum veya örnek üzerinde çalışması olarak tanımlanmıştır.

Ölçek geliştirme çalışmalarındaki önerilerden biri, örneklem büyüklüğü ile madde sayısı oranının 5 ila 10 katı olması yönündedir (MacCallum, Widaman, Zang \& Hong, 1999'dan akt. Erkuş, 2014, s.99). Bryman ve Cramer (2001), faktör analizinde katılımcı sayısı belirlenirken, ölçekteki madde sayısının beş ya da on ile çarpılmasıyla elde edilen değerin ölçüt olarak alınması gerektiğini ileri sürmektedir. Kline (1994) ise, 200 kişilik örneklemin genellikle yeterli olacağını ancak faktör yapısının açık ve az sayıda olduğu durumlarda bu rakamın 100’e kadar indirilebileceğini belirtmektedir. Araştırmanın çalışma grupları göz önünde bulundurulduğunda hem geçerlik hem de güvenirlik analizleri için çalışma gruplarının yeterli büyüklükte olduğu söylenebilir (Seçer, 2013b, s. 90).

\section{Veri toplama araçları}

Araştırmacı tarafından geliştirilen "Türk Dili ve Edebiyatı Öğretmenleri Ölçme Değerlendirme Tutum Ölçeği”ne ait olan maddeler yazılmadan önce ölçek geliştirmeyle ilgili dersler takip edilmiş, gerekli kaynaklar okunmuş ve alana ilişkin bilgi edinilmiştir. Sonrasında tutumların ölçülmesine ilişkin yapılan çalışmalar taranmıştır. Bunların yanı sıra taslak ölçek formunun oluşturulması esnasında hem çalışmayla ilgili literatür hem de diğer araştırmacılar tarafından geliştirilen ve farklı ders alanlarıyla ilgili tutum ölçekleri incelenmiş madde yazım aşamasına geçilmiştir. Alan yazında çeşitli derslere yönelik geliştirilen tutum ölçekleri (Arslan, 2012; Aytan, 2016; Demir ve Koç, 2013; Duatepe ve Çilesiz, 1999; Güllü ve Güçlü, 2009; Kenar ve Balc1, 2012; Karaca, 2015; Karagöz vd.,2016; Karakaş Türker ve Turanll, 2008; Koçakoğlu ve Türkmen, 2010; Lehimler ve Cengiz, 2018; Sayın, 2016; Seçer, 2013; Topçuoğlu Ünal ve Köse, 2014; Ulu Kalın ve Topkaya, 2017; Varış ve Cesur, 2012; Yaşar, 2014; Yeşilyurt ve Gül, 2009) ve çalışmalar da incelenerek 84 maddelik bir madde havuzu oluşturulmuştur. Araştırmacı tarafından hazırlanan 84 maddelik taslak ölçek formu Atatürk Üniversitesi Eğitim Fakültesinde bulunan 4 ölçme değerlendirme uzmanı ve 2 dil uzmanının görüşüne sunulmuştur. Uzman dönütleri dikkate alınarak gerekli düzeltmeler yapılmıştır. Sonuç olarak uzman görüşünden önce 84 maddeden oluşan (Maddelerin bir kısmı olumlu, bir kısmı olumsuz cümlelerden oluşmuştur.) madde havuzu uzman görüşleri neticesinde 53 maddeye düşürülerek taslak ölçek formu oluşturulmuştur. Taslak hâlindeki ölçeğin cevaplama süresinin belirlenmesi ve maddelerin anlaşlabilirliğinin kontrolü amaciyla Ölçme Değerlendirme dersi almış 50 öğretmen üzerinde ön deneme uygulaması gerçekleştirilmiştir. Uygulama sonucu ölçeğin cevaplama süresi 15 ile 20 dakika arasında değiştiği bulunmuş ve ölçek maddelerinin anlaşılabilir olduğu iki maddenin ise anlaşılmadığı tespit edilmiştir. Pilot uygulama sonucu maddetoplam korelasyon değerlerinin yanı sıra Cronbach Alpha değerleri incelenmiştir. Bu aşamadan sonra 
ise bazı maddeler tekrar gözden geçirilip yeniden ifade edilmiştir. Fakat 5 maddenin ölçek toplamı ile yeterli uyum göstermediği belirlenmiştir. Bu maddelerin madde toplam korelasyon değerlerinin .30’un altında olduğunun belirlenmesi ile ölçekten çıkarılmasına karar verilmiştir. Anlaşılmayan bu maddeler de ölçekten çıkarılarak 48 maddelik ölçek formu hazırlanmıştır. Hazırlanan bu ölçek formu üzerinde geçerlik analizlerinin yanı sıra güvenirlik analizleri yapılmıştır. Geçerlik ve güvenirlik analizleri esnasında toplanmış veriler bilgisayar ortamına aktarılmıştır. Aktarılan bu veriler ile normallik, eksik veri, doğrusallık, uç değer ve multicollinearity analizleri yapılmıştır. Bu analizler doğrultusunda, veri setinde belirlenen ve kabul edilebilir düzeylerde olan boşluklar aritmetik ortalama yardımı ile doldurulmuştur.

\section{Veri analizi ve işlem}

Çalışma grubunun oluşturulması sırasında; öğretmenler araştırmanın amacı hakkında bilgilendirilmiş ve ölçekleri düşüncelerini doğru yansıtacak şekilde doldurmaları istenmiştir. Çalışma esnasında öğretmenlerin gönüllü katılım göstermelerine özen gösterilmiştir. Bu kapsamda okullara birden çok defa ziyaretlerde bulunulmuş ve uzaktan takip edilen ölçeklerle ilgili Türk dili ve edebiyatı öğretmenleri ile iletişim hâlinde olunmuştur. Çalışmanın önemi ve gerekçesi öğretmenler ile paylaşılarak çalışmaya gereken özeni göstermeleri istenmiştir. Çalışmaya katılmak istemeyen öğretmenler, ölçekleri tam ve doğru doldurmayan öğretmenler çalışmaya dâhil edilmemiştir. Sonuç olarak toplanan ölçeklerden 19 tanesinde eksik ve yanlışlar tespit edilmesi sonucu çalışma dışında bırakılmıştır. Elde edilen ölçek verileri bilgisayar ortamına aktarılarak veri analizi işlemine geçilmiştir.

Mevcut verilerin faktör analizine geçilmiştir. Faktör analizi, bir veri azaltma tekniği olarak kullanılmaktadır. Büyük bir veri setini alır ve daha küçük bir faktörler ya da bileşenler seti kullanarak bu verileri azaltmanın ya da özetlemenin bir yolunu arar. Faktör analizi, testlerin ve ölçeklerin geliştirilmesi ve değerlendirilmesi ile uğraşan araştırmacılar tarafından yoğun bir biçimde kullanılmaktadır (Pallant, 2016, s. 199). Faktör analizinde literatürde tanımlanan iki temel yaklaşım bulunmaktadır bunlar; açımlayıcı faktör analizi ve doğrulayıcı faktör analizi olarak ifade edilmektedir. Açımlayıcı faktör analizi, bir değişkenler grubu arasındaki karşılıklı ilişkiler hakkında daha fazla bilgi toplamak için genellikle araştırmanın başlangıç safhalarında kullanılır. Doğrulayıcı faktör analizi ise bir dizi değişkenin temelinde yatan yapı ile ilgili belirli kuram ve hipotezleri test etmek (doğrulamak) için araştırmanın ilerleyen süreçlerinde kullanılan daha karmaşı ve gelişmiş bir tekniktir (Pallant, 2016, s. 199).

Türk Dilli ve Edebiyatı Öğretmenleri Tutum Ölçeği’nin geçerlik çalışması iki aşamada yapılmış olup ilk olarak kapsam geçerliği ve daha sonra yapı geçerliği aşamalarında sınanmıştır. Kapsam geçerliği; "testi oluşturan maddelerin ölçülen davranışlar evrenini temsil etme düzeyi hakkında bir karara varma” (Tan, 2014, s. 188) olup "ölçülmek istenilen alanı temsil edip etmediği sorunu ile ilgili olup 'uzman görüşüne' göre saptanır" (Karasar, 2010, s. 151). Yapılan bu çalışmada hazırlanan ölçeğin kapsam geçerliğini belirlemek üzere 4 ölçme değerlendirme uzmanı ve 2 dil uzmanının görüşlerine başvurulmuştur. "Yapı geçerliği ise ölçmenin dayandığı temel kuramların geçerliği ile ilgilidir. Yani önceden kabul edilen olası neden-sonuç ilişkileri ile ilgilidir" (Karasar, 2010, s. 152). "Yapı geçerliliğini incelemek amacıyla sık kullanılan iki yöntem, faktör analizi ve hipotez testidir” (Büyüköztürk vd., 2008, s. 108). Araştırmada yapı geçerliliğini ortaya çıkarmak amacıyla faktör analizi kullanılmıştır. Faktör analizi ise "değişkenler arasındaki ilişkilere dayanarak çok sayıdaki değişkeni daha az sayıdaki değişkene indirebilen çok değişkenli bir analiz tekniğidir" (İslamoğlu ve Alnıaçık, 2013, s. 367). Faktör analizi açımlayıcı ve doğrulayıcı faktör analizi şeklinde ikiye ayrılabilir. Bunlardan açımlayıcı faktör analizi "değişken 
azaltma ve ortaya çıkan faktörleri isimlendirmenin ötesinde, faktör analizi sonucunda ortaya çıkan faktörlerin, davranışın anlaşılmasına yardımcı olan kuramın yapıları ile benzer olup olmadı ̆̆ını ortaya koyar" (Çokluk, Şekercioğlu ve Büyüköztürk, 2014, s. 177). Doğrulayıcı faktör analizinde ise "kuramsal bir yapı doğrultusunda geliştirilen ölçme aracından elde edilen verilere dayanarak, söz konusu yapının doğrulanıp doğrulanmadığı test edilmeye çalışılır” (Çokluk, Şekercioğlu ve Büyüköztürk, 2014, s. 177). Araştırmanın yapı geçerliğini açıklamak için hem açımlayıcı ve hem de doğrulayıcı faktör analizi kullanılmıştır.

Ölçeğin model uyumu DFA ile ve örtük yapısı AFA ile incelenmiştir. DFA'da çoklu uyum indeksleri (RMR, REMSEA, SRMR, CFI) kullanılmıştır. DFA'da CFI, için >.90 kabul edilebilir sınır değer ve $>.95$ mükemmel uyum sınır değeri olarak kabul edilmiştir. RMSEA, SRMR ve RMR için de <.o8 kabul edilebilir sınır değer ve <.50 mükemmel uyum sınır değeri olarak kabul edilmiştir (Cole, 1987, Hu ve Bentler, 1999; Marcoulides ve Schumacher, 2001'den akt. Seçer, 2013b, s. 92). Ayrıca DFA'daki kare değerinin 3 'ün altında olması gerektiği ileri sürülmektedir (Marcoulides ve Schumacher, 2001; Schumacher ve Lomax, 2004; ve Kline, 2005'den akt. Seçer, 2013b, s. 92).

\section{Bulgular}

\section{Türk Dili ve Edebiyatı Öğretmenleri Ölçme Değerlendirme Tutum Ölçeği’nin açımlayıcı faktör analizine ilişkin bulgular}

Açımlayıcı faktör analizinde ölçekte yer alacak maddelerin belirlenmesinde maddelerin öz değerlerinin en az 1.0o, madde faktör yük değerinin en az .30, maddelerin tek bir faktörde yer alması ve iki farklı faktör arasında yeterli faktör yük değerine sahip olan maddelerde ise, en az .10 fark olmasına dikkat edilmiştir (Schriesheim ve Eisenbach, 1995; Seçer, 2013a akt. Seçer 2013b).

Açımlayıcı faktör analizi yapılırken çalışma grubundan elde edilen verilerin faktör analizine uyumunu test etmek maksadıyla Kaiser-Meyer-Olkin (KMO) ve Barlett testleri yapılmış ve KMO .933 bulunmuştur. Barlett testi $\chi 2$ değeri de 3459,889 (p< .001) olarak elde edilmiştir. Field (2009) ve Pallant (2016)'in ifade ettiği üzere KMO'nun .6o'dan yüksek çıkması, Barlett Testi'nin de anlamlı çıkması mevcut verilerin faktör analizi yapılması için uygun olduğu biçiminde değerlendirilmiştir. Açımlayıcı faktör analizi sonucu elde edilmiş olan bulgular Tablo 1'de gösterilmiştir.

Tablo 1: Türk Dili ve Edebiyatı Öğretmenleri Ölçme Değerlendirme Tutum Ölçeği Madde Faktör Yükleri, Açıkladığı Varyanslar ve Madde Analizleri

\begin{tabular}{|c|c|c|c|c|}
\hline$\frac{\mathfrak{z}}{\mathfrak{Z}}$ & :ְ̃ & 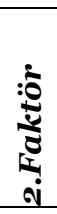 & :⿹弋 & 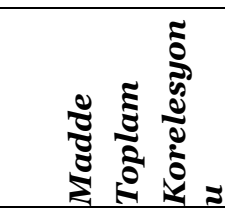 \\
\hline$T 18$ & ,883 & & & ,724 \\
\hline T24 & ,880 & & & 687 \\
\hline T2O & ,865 & & & 669 \\
\hline T19 &, 851 & & &, 761 \\
\hline$T 23$ & ,847 & & & ,729 \\
\hline T3O & ,796 & & & ,570 \\
\hline T16 & 694 & & & 693 \\
\hline
\end{tabular}




\begin{tabular}{l|lll}
$T 29$ &, 690 & &, 601 \\
$T 22$ &, 670 & &, 486 \\
$T 15$ &, 601 & &, 636 \\
$T 12$ &, 478 & &, 545 \\
$T 26$ &, 337 & &, 258 \\
$T 2$ & &, 892 &, 670 \\
$T 5$ &, 830 &, 721 \\
$T 4$ &, 797 &, 643 \\
$T 3$ &, 748 &, 650 \\
$T 1$ &, 561 &, 423 \\
$T 13$ &, 347 &, 945 &, 429 \\
$T 46$ & &, 844 &, 728 \\
$T 47$ & &, 765 &, 746 \\
$T 48$ & &, 491 &, 703 \\
$T 42$ & & &, 574 \\
\hline
\end{tabular}

AFA sonucunda toplam varyansın \%62.29'unu açıklayan 3 faktörlü bir yapı elde edilmiştir. Bu faktörlerin birincisi; T18, T24, T20, T19, T23, T30, T16, T29, T22, T15, T12, T26 maddelerinden oluşan önem alt boyutudur.

İkincisi; T2, T5, T4, T3, T1, T13 maddelerinden oluşan bilgi alt boyutudur.

Üçüncüsü; T46, T47, T48, T42 maddelerinden oluşan fayda alt boyutudur. Ayrıca açımlayıcı faktör analizinde Maksimum Olabilirlik Tekniği ve Promax döndürme yöntemi kullanılmıştır.

Ölçeğin geneline bakıldığında madde faktör yük değerlerinin .33 ile .94 arasında değiştiği belirlenmiştir. Tabachnick ve Fidell (2001) ölçek geliştirme sürecinde madde faktör yük değerlerinin alt sınırının .32 olması gerektiğini ifade etmektedir. Elde edilen veriler ışığında ölçeğin üç faktörlü yapısının madde faktör yük değerlerinin yeterli düzeyde olduğu ifade edilebilir. Ölçeğin açıkladığı toplam varyans ve alt boyutların varyansları ise; Birinci alt boyut toplam varyansın 49,004'ünü, ikinci alt boyut toplam varyansın 7,301'ini, üçüncü alt boyut toplam varyansın 5,723'ünü açılamaktadır. 22 maddeden oluşan ölçeğin toplam açıklanan varyans değeri ise, \% 62,29 olarak bulunmuştur.

Madde toplam korelasyon değerinin yorumunda değeri .3o ve üzerindeki maddelerin ölçülecek özelliği ayırt etme açısından yeterli kabul edildiği ve ölçek toplamı ile uyumlu olduğu (Field, 2009; Erkuş, 2014) göz önünde bulundurulduğunda, ölçekteki maddelerin ölçek toplam puanı ile orta ya da yüksek düzeyde ilişkili olduğu ve madde geçerliliğinin sağlandığı ifade edilebilir. Ancak ölçekteki bir maddenin bu değerin altında kaldığı görülmektedir. Bu maddenin de yapısı itibarıyla ölçekten çıkarılmaması ve DFA sonuçlarına bakılması yapılan uzman görüşmeleri neticesinde uygun görülmüştür.

Türk Dili ve Edebiyatı Öğretmenleri Ölçme Değerlendirme Tutum Ölçeği faktörleri arasındaki ilişkiyi belirlemek amacıyla faktörler arası korelasyona bakılmıştır. Alt boyutlar arasındaki korelasyon katsayısının çoklu bağıntı (Multicollinearity) problemi açısından elde edilen korelasyon katsayısının .90 ve üzerinde bulunmaması önerilmektedir (Pallant, 2016; Field, 2009). 
A scale development study to determine the assessment and evaluation attitudes of Turkish language and literature teachers: Validity and reliability / B. Gücüyeter; A. Karadoğan (pp. 47-6o)

Tablo 2: Türk Dili ve Edebiyatı Öğretmenleri Ölçme Değerlendirme Tutum Ölçeği Alt Boyutları Arasındaki Korelasyonlar

\begin{tabular}{llll}
\hline & 1 & 2 & 3 \\
\hline 1. Boyut & 1 & & \\
\hline 2. Boyut &, 642 & 1 & 1 \\
\hline 3. Boyut &, 621 &, 454 & \\
\hline
\end{tabular}

Tablo 2'de Türk Dili ve Edebiyatı Öğretmenleri Ölçme Değerlendirme Tutum Ölçeği alt boyutları arasındaki korelasyon değerleri görülmektedir. Elde edilen veriler ölçeğin üç alt boyutu arasında anlamlı düzeyde ilişkiler olduğunu ve çoklu bağıntı probleminin bulunmadığını göstermektedir.

\section{Türk Dili ve Edebiyatı Öğretmenleri Ölçme Değerlendirme Tutum Ölçeği’nin doğrulayıcı faktör analizine ilişkin bulgular}

Türk Dili ve Edebiyatı Öğretmenleri Ölçme Değerlendirme Tutum Ölçeği’nin açımlayıcı faktör analizi sonucu elde edilen 3 faktörlü yapısının model uyumu doğrulayıcı faktör analizi ile incelenmiş ve elde edilen bulgular Şekil 1'deki gibidir.

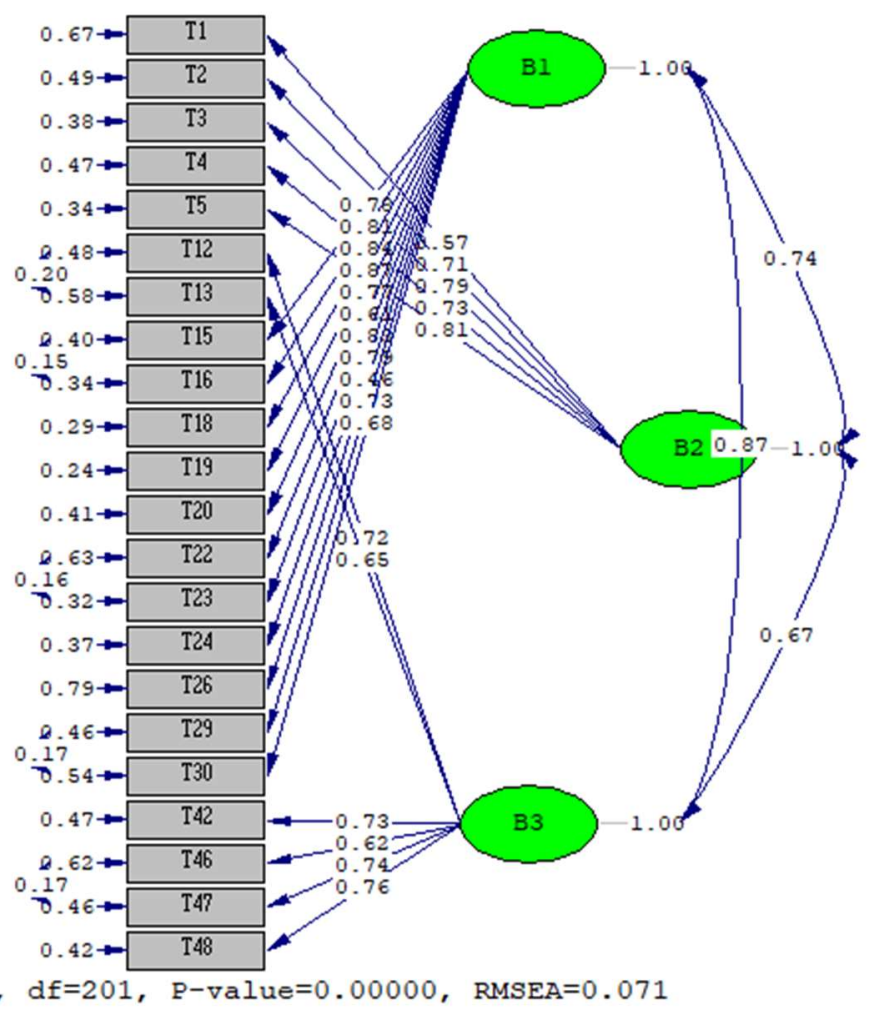

Şekil 1: Türk Dili ve Edebiyatı Öğretmenleri Ölçme Değerlendirme Tutum Ölçeği’nin DFA Sonuçları

Şekil 1'in incelenmesi sonucu, 22 madde ve 3 alt faktörden oluşan Türk Dili ve Edebiyatı Öğretmenleri Ölçme Değerlendirme Tutum Ölçeği'nin uyum indekslerinin anlamlı olduğu görülmektedir (X2= 434,74, sd=201, p=.00, X2/sd=2.1). Uyum indeksi değerleri ise, RMSEA=.071, SRMR: .054, RMR= $.034, \mathrm{NFI}=.96, \mathrm{NNFI}=.98, \mathrm{CFI}=.98, \mathrm{IFI}=.98, \mathrm{RFI}=.96, \mathrm{GFI}=.85$ olarak bulunmuştur. DFA analizinde oluşturulan bu yapısal modelin uyum indekslerinin tamamının iyi düzeyde olduğu söylenebilir. 
DFA analizinde 12 ile 13, 15 ile 16, 22 ile 23, 29 ile 30, 46 ile 47. maddeler arası modifikasyon önerileri doğrultusunda modifikasyon işlemi yapılmış ve modelin modifikasyonlardan sonra daha iyi uyum sağladığı gözlenmiştir. Yapılan DFA sonucu 12 ve 13. maddelerin 3. boyut altında değerlendirilmesinin model uyumuna katkı sağladığı görülmüştür. Bu kapsamda 12 ve 13. maddeler 3. boyut altında değerlendirilmiştir. Böylece birinci alt boyutun T18, T24, T20, T19, T23, T30, T16, T29, T22, T15, T26 maddelerinden, ikinci alt boyutun $\mathrm{T}_{2}, \mathrm{~T}_{5}, \mathrm{~T} 4, \mathrm{~T} 3$, T1 maddelerinden, üçüncü alt boyutun $\mathrm{T}_{4} 6, \mathrm{~T}_{4}$, $\mathrm{T}_{4} 8$, T42, T12, T13 maddelerinden oluştuğu görülmüştür. Standart çözümlerden sonra faktörler ve maddeler arasındaki t değerlerine bakılmıştır. $t$ değerleri ile ilgili kırmızı ok bulunmamasının tüm maddelerin .05 düzeyinde anlamlı olduğunu ifade etmektedir (Seçer, 2013). T değerlerinde kırmızı ok bulunmaması tüm maddelerin .05 düzeyinde anlamlı olduğunu göstermiştir. Ölçek formuna son hâli verilirken birinci alt boyuta ait maddeler; T15-1, T16-2, T18-3, T19-4, T20-5, T22-6, T23- 7, T24-8, T26-9, T29-10, T3011 olarak, ikinci alt boyuta ait maddeler; T1-12, T2-13, T3-14, T4-15, T5-16 olarak, üçüncü alt boyuta ait maddeler T12-17, T13-18, T42-19, T46-20, T47-21, T48-22. maddeler olarak yeniden siralanmış ve ölçeğin son hâli Ek 1'de verilmiştir.

\section{Güvenirlik analizi}

Türk Dili ve Edebiyatı Öğretmenleri Ölçme Değerlendirme Tutum Ölçeği'nin güvenirliğini incelemek amacıyla iç tutarlık ve iki yarı güvenirliği analizleri uygulanmıştır. Ortaya çıan bulgular Tablo 3'de verilmiştir.

Tablo 3: Türk Dili ve Edebiyatı Öğretmenleri Ölçme Değerlendirme Tutum Ölçeği’nin İç Tutarlık ve İki Yarı Güvenirlik Yöntemiyle Hesaplanan Güvenirlik Katsayıları

\begin{tabular}{lll}
\hline Boyutlar & İç Tutarlık & İki Yarı Güvenirlik \\
\hline 1. Boyut & .929 & .901 \\
2. Boyut & .852 & .837 \\
3. Boyut & .838 & .827 \\
Toplam Ölçek & .946 & .888 \\
\hline
\end{tabular}

Türk Dili ve Edebiyatı Öğretmenleri Ölçme Değerlendirme Tutum Ölçeği’nin güvenirlik analizi için yapılan iç tutarlılık ve iki yarı güvenirlik işlemlerinin tamamında ölçeğin toplamı ve alt boyutları için elde edilen güvenirlik katsayılarının iyi düzeyde olduğu ve ölçeğin genelinin ve alt boyutlarının bu hâliyle iç tutarlılığa ve güvenirliliğe sahip olduğu söylenebilir. Ölçek geliştirme ve uyarlama süreçlerinde güvenirlik katsayısı .70 ve üzerinde olan ölçeklerin güvenilir kabul edildiği göz önüne alındığında Türk Dili ve Edebiyatı Öğretmenleri Ölçme Değerlendirme Tutum Ölçeği’nin iç tutarlık, iki yarı ve test tekrar test güvenirlik katsayılarının yeterli olduğu söylenebilir (Landis ve Koch, 1977; Robinson, Shaver, ve Wrightsman, 1991).

\section{Sonuç ve tartışma}

Türkiye'nin eğitim misyonu- Türk edebiyatı ile dil ve anlatım programlarının temel felsefesini de dikkate alarak söyleyebiliriz ki-, "yüksek karakterli ve nitelikli”, "millî değerlere bağlı”, "Türkçe’nin önemini bilen" bireylerin yetiştirilmesidir (Çetin \& Eskimen, 2016, s. 49). Bu bireylerin yetiştirilmesinde de en önemli görev Türk dili ve edebiyatı öğretmenlerine düşmektedir. Nitelikli ve istenen düzeyde bireylerin yetiştirilmesinde öğretim faaliyetlerinin etkinliğini belirlemek kadar öğretim etkinliklerinin değerlendirilmesi de önemlidir. 
A scale development study to determine the assessment and evaluation attitudes of Turkish language and literature teachers: Validity and reliability / B. Gücüyeter; A. Karadoğan (pp. 47-6o)

Eğitimde birçok nitelik ölçülebilir. Bunlar çoğu hâlde öğrencilerin birtakım özellikleridir. Bu nedenle ölçme işlemi her zaman ölçülecek niteliğin tanımlanmasıyla başlar. Ölçme, araç gerektirir. Ölçme araçları, ölçülecek niteliğin gözlenip sayılarla ifade edilmesini kolaylaştırır. Her araç, bir bakıma, gözlemin daha duyarlı yapılmasını sağlar. Eğitimde kullanılan ölçme araçları, ölçülecek niteliğin doğasına ve aracın kullanılacağı gruba göre çeşitlilik gösterir. Ölçmeyi yapacak kimse, değerlendirmenin amacına uygun bir araç seçmek, yoksa böyle bir aracı bizzat yapmak durumundadır (Turgut \& Baykul, 2015, s. 5).

Yapılan literatür taramasında bulunan ölçeklerin güvenirlikleri ve uygulanan örneklemi bağlamında uzman görüşleri de alınarak Türk dili ve edebiyatı öğretmenlerinin ölçme değerlendirme algılarını ölçebilecek güvenli ve geçerli bir ölçek geliştirme çalışmasının gerekli olduğu kanısına varılmıştır. Bu kapsamda yapılan bu çalışma ile alanda ki bu boşluk giderilmeye çalışılmıştır. Bu amaçla Türk Dili ve Edebiyatı Öğretmenleri Ölçme Değerlendirme Tutum Ölçeği geliştirilmiş ve geçerlik-güvenirlik analizleri yapılmıştır.

Ölçek geliştirme aşamasında literatür taraması yapılmıştır. Oluşturulan madde havuzunun alan uzmanlarının görüşüne sunulmasının ardından pilot uygulamalar yapılarak madde uyumları incelenmiştir. Pilot uygulama sonrası ölçeğin faktör yapısını belirlemek amacıyla AFA yapılmış ve toplam varyansın \%62.29'unu açıklayan üç boyutlu bir yapı elde edilmiştir. Kline (2011) ölçek geliştirme ve uyarlama çalışmalarında elde edilen açıklanan varyans oranının minimum \%40 olması gerektiğini belirtirken, bazı kaynakalrda ise, bu oranın en az \%52 veya üzerinde olması gerektiğini ifade etmektedir. Bu kapsamda çalışmanın açımlayıcı faktör analizi sonucu elde edilen değerin ölçeğin faktör yapısına karar vermek için yeterli düzeyde olduğu ifade edilebilir. AFA'dan elde edilen faktör yapısının model uyumu DFA ile incelenmiş ve model uyum indekslerinin yeterli olduğu bulunmuştur (X2 $=434,74$, $\mathrm{sd}=201, \mathrm{p}=.00, \mathrm{X} 2 / \mathrm{sd}=2.1, \mathrm{RMSEA}=.071$, SRMR: .054, RMR $=.034, \mathrm{NFI}=.96, \mathrm{NNFI}=.98, \mathrm{CFI}=.98$, $\mathrm{IFI}=.98, \mathrm{RFI}=.96, \mathrm{GFI}=.85$ ) DFA'dan elde edilen uyum indeks değerleri ölçeğin model uyumunun yeterli düzeyde olduğunu göstermektedir denilebilir (Marcoulides ve Schumacher, 2001; Schumacher ve Lomax, 2004; ve Kline, 2011). Türk Dili ve Edebiyatı Öğretmenleri Ölçme Değerlendirme Tutum Ölçeği model uyumunun belirlenmesinden sonra ortaya konulan 3 faktörlü yapı ilgili literatür taraması ve kuramsal görüşler doğrultusunda birinci alt boyut önem, ikinci alt boyut bilgi, üçüncü alt boyut fayda olarak isimlendirilmiştir.

Türk Dili ve Edebiyatı Öğretmenleri Ölçme Değerlendirme Tutum Ölçeği güvenirliğini belirlemek amacıyla iç tutarlık, iki yarı güvenirlik yöntemleri kullanılmıştır. Yapılan analizler sonucunda ölçeğin hem alt boyutlar bakımından hem de toplam puan açısından iç tutarlık, iki yarı güvenirliğine sahip olduğu belirlenmiştir. Ölçek geliştirme çalışmalarında ölçeklerin güvenilir kabul edilebilmesinde genel olarak .70 ve üzerinde bir güvenirlik değerine sahip olması gerektiği ifade edilmiştir (Landis ve Koch, 1977; Robinson, Shaver ve Wrightsman, 1991). Eldeki bulgular neticesinde Türk Dili ve Edebiyatı Öğretmenleri Ölçme Değerlendirme Tutum Ölçeği iç tutarlık, iki yarı güvenirliğine sahip olduğu ifade edilebilir.

Bu araştırmada Türk Dili ve Edebiyatı Öğretmenleri Ölçme Değerlendirme Tutum Ölçeği geçerlik ve güvenirlik analizleri sadece yukarıda belirtilen illerdeki liselerde görev yapan öğretmenlerden ulaşılabilen örneklem ile yapılmıştır. Dolayısıyla bu illerde ulaşılamayan ve bu iller dışındaki öğretmenler ile ölçeğin geçerlik ve güvenirlik çalışmasının mevcut kısıtlar sebebiyle yapılamamış olması ölçeğin önemli bir sınırlılığı olarak ifade edilebilir. Bu kapsamda bundan sonra yapılacak çalışmalarda 
ölçeğin geçerlik ve güvenirlik çalışmasının Türkiye'nin farklı bölgelerinde ve aynı zamanda liselerde görev yapan öğretmenleri kapsayacak şekilde yeniden yapılması önerilebilir.

\section{Kaynakça}

Arslan, A. (2012). Yükseköğretimde Türk Dili Dersine Karsı Tutum Ölçeği Geçerlik ve Güvenirlik Çalışması. Uluslararası Türkçe Edebiyat Kültür Eğitim Dergisi, 1(3), 187-202.

Aytan, N. (2016). “Türkçe Dersi Tutum Ölçeği” Geliştirme Çalışması. Kastamonu Eğitim Dergisi, 24 (2), 535-546. Retrieved from http://dergipark.org.tr/kefdergi/issue/22590/241272

Büyüköztürk, Ş. (2014). Sosyal Bilimler İçin Veri Analizi El Kitabı. Ankara: Pegem Akademi Yayıncılık.

Büyüköztürk, Ş., Kılıç Çakmak, E., Akgün, Ö. E., Karadeniz, Ş. \& Demirel, F. (2013). Bilimsel Araştırma Yöntemleri. Ankara: Pegem Akademi Yayınları.

Bryman, A. \& Cramer, D. (2001). Quantitative data analysis with SPSS release 10 for Cole, D.A. (1987). Utility of confirmatory factor analysis in test validation research. Journal of Consulting and Clinical Psychology, 55, 1019-1031.

Cemiloğlu, M. (2003). Türk Dili ve Edebiyatı Ö̆gretimi. Alfa Yayınları. İstanbul

Çetin, İ., \& Eskimen, A. D. (2016). Türkiye ve Amerika'da Dil-Edebiyat Öğretimi. Dil ve Edebiyat Eğitimi Dergisi, (17), 45-69.

Çokluk, Ö.,Şekercioğlu, G. \& Büyüköztürk, Ş. (2014). Sosyal Bilimler İçin Çok Değişkenli İstatistik SPSS ve LISREL Uygulamaları. Ankara: Pegem Akademi Yayıncılık.

Demir, S. B. \& Koç, H. (2013). Coğrafya Dersi Tutum Ölçeği: Geliştirilmesi, Geçerlik ve Güvenirlik Çalışması. Turkish Studies - International Periodical For The Languages, Literature And History Of Turkish Or Turkic Volume 8/8, 1765-1777

DeVellis, R. F., (2014). Ölçek Geliştirme Kuram ve Uygulamalar (Çeviri Edt: Tarık Totan), Nobel Akademik Yayıncılık. Ankara

Duatepe, A. \& Çilesiz, Ş. (1999). Matematik Tutum Ölçeği Geliştirilmesi. Hacettepe Üniversitesi Eğitim Fakültesi Dergisi, 16-17 : 45- 52.

Erkuş, A. (2014). Psikolojide ölçme ve ölçek geliştirme 1: Temel kavramlar ve işlemler. Pegem Akademi Yay. Ankara

Field, A. (2009). Discovering Statistic Using SPSS for Windows. London: SAGE Publications

Güllü, M. \& Güçlü, M. (2009). Ortaöğretim Öğrencileri İçin Beden Eğitimi Dersi Tutum Ölçeği Geliştirilmesi. Niğde Üniversitesi Beden Eğitimi ve Spor Bilimleri Dergisi, 3(2), 138-151.

İslamoğlu, A. H. \& Alnıaçık, Ü. (2013). Sosyal Bilimlerde Araştırma Yöntemleri (SPSS uygulamalı). İstanbul: Beta Yayıncllı.

Karagöz, Y., Bardakçı, S., Demir, B., Arslan, R., Yemez, İ. (2016). İ̈BF Öğrencilerine Yönelik Matematik Tutum Ölçeği Geliştirilmesi. Ekonomik ve Sosyal Araştırmalar Dergisi, 12 (2), 39-55. Retrieved from http://dergipark.org.tr/esad/issue/38969/456206

Karaca, E. (2015). Öğretimde Planlama ve Değerlendirme Dersine Yönelik Bir Tutum Ölçeği Geliştirme. Dumlupınar Üniversitesi Sosyal Bilimler Dergisi, (16), . Retrieved from http://dergipark.org.tr/dpusbe/issue/4758/65363

Karakaş Türker, N. \& Tưranll, N. (2008). Matematik Eğitimi Derslerine Yönelik Tutum Ölçeği Geliştirilmesi. Gazi Üniversitesi Gazi Eğitim Fakültesi Dergisi, 28(3), 17-29.

Karasar, N. (2010). Bilimsel Araştırma Yöntemi. Ankara: Nobel Yayın Dağıtım.

Kayış, A. (2014). Güvenilirlik Analizi. Kalaycı, Ş. (Editör), SPSS Uygulamalı Çok Değişkenli İstatistik Teknikleri. (s. 404-409). Ankara: Asil Yayın Dağıtım.

Kenar, İ. \& Balcı, M. (2012). Fen ve Teknoloji Dersine Yönelik Tutum Ölçeği Geliştirme: İlköğretim 4 ve 5. Sını Örneği. Dumlupınar Üniversitesi Sosyal Bilimler Dergisi, Sayı 34, 201-210. 
A scale development study to determine the assessment and evaluation attitudes of Turkish language and literature teachers: Validity and reliability / B. Gücüyeter; A. Karadoğan (pp. 47-6o)

Kizlik. B (2012) Measurement, Assessment and Evaluation in Education. Robert Kizlik and Associates Boca Raton, Florida. Retrieved From Http/Www.Adprima.Com Measurement. Htm. On The 3oth June, 2012.

Kline, R.B. (2011). An Easy Guide to Factor Analysis.New York: The Guilford Press

Koçakoğlu, M. \& Türkmen, L. (2010). Biyoloji Dersine Yönelik Tutum Ölçeği Geliştirilmesi. Ahi Evran Üniversitesi Eğitim Fakültesi Dergisi, 11(2), 229-245.

Landis, J. R., \& Koch, G. G. (1977). The measurement of observer agreement for categorical data. Biometrics, 33, 159-174

Lehimler, E. \& Cengiz, C. (2018). Armoni Dersine İlişkin Tutum Ölçeği Geliştirme Çalışması. Güzel $\begin{array}{lllll}\text { Sanatlar Enstitüsü Dergisi, (40), 42-55. Retrieved from } & \end{array}$ http://dergipark.org.tr/ataunigsed/issue/36820/411076

Marcoulides, G. \& Schumacher, R. (2001). New developments and Technıques in structural Equation modelıng. London: Lawrence Erlbaum Associates, Publıshers

MEB. (2018). Türk Dili ve Edebiyatı 9, 10, 11, 12. Sinıflar Öğretim Programı. Ankara

Pallant, J. (2016). SPSS kullanma kılavuzu. SPSS ile adım adım veri analizi (Çev. Ed. S. Balcı ve B. Ahi). Anı Yay.

Robinson, J. P.; Shaver, P. R., \& Wrightsman, L. S. (1991). Criteria for Scale Selection and Evaluation in Measure of Personality and Social Psychological Attitudes. San Diego: California Academic Press.

Sayın, A. (2016). Sözlü Anlatım Dersine Yönelik Tutum Ölçeği: Geçerlik ve Güvenirlik Çalışması. Amasya Üniversitesi Eğitim Fakültesi Dergisi, 5 (2), 447-467. Retrieved from http://dergipark.org.tr/amauefd/issue/27423/288459

Seçer, İ. (2013a). SPSS ve LISREL İle Pratik Veri Analizi Analiz ve Raporlaştırma. Ankara: Anı Yayıncilik.

Seçer, İ. (2013b). Zorbalıkla Başa Çıkma Stratejileri Ölçeğinin Geliştirilmesi: Geçerlik ve Güvenirlik Çalışması. Atatürk Üniversitesi Kazım Karabekir Eğitim Fakültesi Dergisi, (30), 85-105.

Schumacher, R.\& Lomax, R. (2004). A Beginner's Guide to Structual Equation Modelling. London: Lawrence Erlbaum Associates, Publishers

Tabachnick, B. G. \& Fidell, L. S. (2001). Using multivariate statistics. Needham Heights, MA: Allyn \& Bacon.

Tan, Ş. (2014). Öğretimde Ölçme ve Değerlendirme Kpss El Kitabı. Ankara: Pegem Akademi yayıncılık.

Tavşancıl, E. (2014). Tutumların Ölçülmesi ve SPSS ile Veri Analizi. Ankara. Nobel Yayıncılık

Turgut, F. \& Baykul, Y. (2015). Eğitimde Ölçme ve Değerlendirme. Pegem Yayınları. Ankara

Topçuoğlu Ünal, F. \& Köse, M. (2014). Türkçe Dersine Yönelik Tutum Ölçeği Geliştirilmesi: Bir Geçerlilik ve Güvenirlik Çalışması. Bartın Üniversitesi Eğitim Fakültesi Dergisi, 3(2), 233 - 249.

Ulu Kalın, Ö. ve Topkaya, Y. (2017). İlkokul 4. Sınıf Sosyal Bilgiler Dersine Yönelik Tutum Ölçeğinin Geçerlilik ve Güvenirlik Çalışması. Mustafa Kemal Üniversitesi Sosyal Bilimler Enstitüsü Dergisi, 14 (37), o-o. Retrieved from http://dergipark.org.tr/mkusbed/issue/44714/555470

Varış, Y \& Cesur, D. (2012). Ortaöğretim Müzik Dersine Yönelik Tutum Ölçeğinin Geliştirilmesi. Fine Arts, 7 (4), 361-374. Retrieved from http://dergipark.org.tr/nwsafine/issue/19894/213054

Yaşar, M. (2014). Eğitimde Ölçme ve Değerlendirme Dersine Yönelik Tutum Ölçeğinin Geliştirilmesi. Eğitim Bilimleri Araştırma Dergisi, 4(1), 259-279.

Yeşilyurt, S. \& Gül, Ş. (2009). Biology Attitude Scale. Erzincan Üniversitesi Eğitim Fakültesi Dergisi, 11 (2), 239-258. Retrieved from http://dergipark.org.tr/erziefd/issue/6001/80031 
Ek 1:

Türk Dili ve Edebiyatı Öğretmenleri Ölçme Değerlendirme Tutum ölçeği

\begin{tabular}{|c|c|c|c|c|}
\hline & 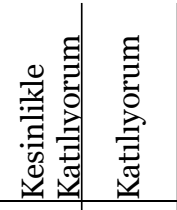 & 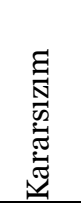 & 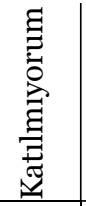 & 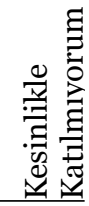 \\
\hline \multicolumn{5}{|l|}{ Önem Alt Boyutu } \\
\hline \multicolumn{5}{|l|}{$\begin{array}{l}\text { 1. Ölçme ve değerlendirme süreçleri öğretimde zamanı daha etkili } \\
\text { kullanabilmeme olanak sağlar. }\end{array}$} \\
\hline \multicolumn{5}{|l|}{$\begin{array}{lllll}\text { 2. Ölçme ve değerlendirme bilgisi } & \text { öğretim } & \text { etkinliklerini } & \text { etkili } \\
\text { düzenleyebilmem bakımından önemlidir. } & & & \end{array}$} \\
\hline \multicolumn{5}{|l|}{$\begin{array}{l}\text { 3. Ölçme ve değerlendirme ders içeriğine göre uygun yöntem belirleyebilmem } \\
\text { bakımından önemlidir. }\end{array}$} \\
\hline \multicolumn{5}{|l|}{$\begin{array}{l}\text { 4. Ölçme ve değerlendirme, ders içeriğine uygun öğretim ortamının } \\
\text { oluşturulması bakımından önemlidir. }\end{array}$} \\
\hline \multicolumn{5}{|l|}{$\begin{array}{l}\text { 5. Ölçme ve değerlendirme öğretmenlik mesleğinin daha işlevsel olarak } \\
\text { yürütülebilmesi bakımından önemlidir. }\end{array}$} \\
\hline \multicolumn{5}{|l|}{$\begin{array}{l}\text { 6. Ölçme değerlendirme süreçlerini öğrenci yeterliklerini ortaya çıkarmak için } \\
\text { kullanırım. }\end{array}$} \\
\hline \multicolumn{5}{|l|}{$\begin{array}{l}\text { 7. Ölçme ve değerlendirme öğretim hedeflerine uygun ölçme araçları } \\
\text { belirleyebilme bakımından önemlidir. }\end{array}$} \\
\hline \multicolumn{5}{|l|}{$\begin{array}{l}\text { 8. Ölçme ve değerlendirmede uygulamalarını bilmek mesleki becerilerin } \\
\text { gelişmesine katkıda bulunur. }\end{array}$} \\
\hline \multicolumn{5}{|l|}{$\begin{array}{l}\text { 9. Ylllık ders planları hazırlanırken ölçme ve değerlendirmeye ayrılan sürenin } \\
\text { artırılması gerektiğine inanıyorum. }\end{array}$} \\
\hline \multicolumn{5}{|l|}{$\begin{array}{l}\text { 10. Ölçme ve değerlendirme süreçlerinin eğitim kalitesini artırdığını } \\
\text { düşünüyorum. }\end{array}$} \\
\hline \multicolumn{5}{|l|}{$\begin{array}{l}\text { 11. Ölçme ve değerlendirme yapmak eğitimde karşlaşılan sorunları } \\
\text { belirlemede önemlidir. }\end{array}$} \\
\hline \multicolumn{5}{|l|}{ Bilgi Alt Boyutu } \\
\hline \multicolumn{5}{|l|}{$\begin{array}{l}\text { 12. Ölçme ve değerlendirme bilgisinin öğrenci başarısını artıracağını } \\
\text { düşünüyorum. }\end{array}$} \\
\hline \multicolumn{5}{|l|}{ 13. Ölçme ve değerlendirme sonuçlarına göre ders sürecini planlarım. } \\
\hline \multicolumn{5}{|l|}{$\begin{array}{l}\text { 14. Ders sürecini planlarken ölçme değerlendirme yaklaşımlarını göz önünde } \\
\text { bulundururum. }\end{array}$} \\
\hline \multicolumn{5}{|l|}{ 15. Ölçme ve değerlendirme benim için ilgi çekicidir. } \\
\hline \multicolumn{5}{|l|}{$\begin{array}{l}\text { 16. Dersi daha verimli hale getirmek için ölçme değerlendirme yaklaşımlarını } \\
\text { kullanırım. }\end{array}$} \\
\hline \multicolumn{5}{|l|}{ Fayda Alt Boyutu } \\
\hline $\begin{array}{l}\text { 17. Ölçme ve değerlendirme öğrenci başarısını farklı değerlendirme } \\
\text { yaklaşımlarıyla yorumlayabilmeme olanak sağlar. }\end{array}$ & & & & \\
\hline \begin{tabular}{r|l} 
Adres & Adress \\
Kurklareli Üniversitesi, Fen Edebiyat Fakültesi, Türk Dili ve Edebiyatut & Kurklareli University, Facul \\
Bölümü, Kayall Kampüsui-Krrklareli/TÜRKIYY & Turkish Language and Lite \\
e-posta: editor@rumelide.com & e-mail: editor@rumelide.
\end{tabular} & $\begin{array}{l}\text { y of Arts and Scie } \\
\text { ature, Kayalı Can } \\
\mathrm{m}\end{array}$ & & & \\
\hline
\end{tabular}


A scale development study to determine the assessment and evaluation attitudes of Turkish language and literature teachers: Validity and reliability / B. Gücüyeter; A. Karadoğan (pp. 47-6o)

18. Ölçme ve değerlendirme öğretim hedeflerine uygun ölçme araçları (başarı testi) geliştirebilmeme katkı sağlar.

19. Ölçme-değerlendirmelerin öğrencilerdeki öğrenme eksikliklerinin tamamlanmasına katkı sağladığını düşünürüm.

20. Ölçme değerlendirme süreçleri öz eleştiri yapmama yardımcı olur.

21. Ölçme ve değerlendirme süreçleri öğretimde zamanı daha etkili kullanabilmeme olanak sağlar.

22. Ölçme ve değerlendirme bilgisi öğretim etkinliklerini etkili düzenleyebilmem bakımından önemlidir. 